\title{
Development of socially significant infrastructure in Russia based on public- private partnership
}

Irina Vaslavskaya*

Kazan Federal University, ul. Kremlyovskaya, 18., 420008, Kazan, the Russian Federation

\begin{abstract}
The global financial crisis of 2007-2009 laid the foundation for a steady trend of slowing economic growth on a global scale, which was accompanied by a reduction in budget revenues of national states and a limitation of state budget spending. In these conditions, objectively, the need arose to form a hierarchy of priority budget expenditures that would allow the state to ensure economic growth and finance the growing social needs of society in the context of entrenched stagnation. Numerous studies have proved that the most acceptable model for the state becomes the development of socially significant infrastructure based on the organization of public-private partnerships (PPP). In the context of budgetary restrictions and the consolidation of budgetary funds, PPP forms objectively come first in order to organize co-financing of projects for the development of socially significant infrastructure. However, in Russia and in other countries of the world PPP projects are being implemented slowly, especially in socially significant infrastructure, which could become a powerful driver of economic growth in the future. In this regard, the problem of creating the conditions necessary to ensure the multiplier effect of budget financing of public infrastructure in conditions of a deficit of public finances is becoming particularly relevant.
\end{abstract}

\section{Introduction}

The first global crisis of the beginning of the 21 st century raised the fundamental question of adequate institutional support for attracting long-term investment in the economy as the main factor in the sustainable development of the countries of the world. The most acceptable investment projects in this regard are recognized as infrastructure facilities built on PPP terms. World Bank experts say that in a situation where global economic growth fluctuates around $3 \%$ per year, infrastructure development is becoming a key factor that can accelerate it [1].

Traditionally, the financing of public infrastructure in the form of PPP projects was carried out mainly at the expense of budgetary funds of authorities at all levels. This is because the provision of the necessary quantity and quality of public infrastructure services was initially imposed on the state. However, as the volume of public goods and services in all countries of the world increased, the problem of a chronic deficit of state budgets and a build-up of public debt was aggravated. The limits of government borrowing in the financial

* Corresponding author: vaslavskaya@yandex.ru 
market are usually restricted at the legislative level, which forces governments to seek ways to reduce current budget expenditures without harming the public goods and services sector, so as not to resort to internal or external loans to finance its deficit. This explains the downward trend in budget investments in infrastructure projects in most countries in recent years [2]. Under these conditions, the question of adequate institutional support for the development of public infrastructure due to the influx of private investment has come up on the agenda.

\section{Budgetary constraints of national governments as an objective basis for the development of PPPs}

The need to expand and deepen the interaction between the state and private business as business partners in modern conditions has increased many times due to the growing slowdown in economic development in almost all countries of the world and the ineffectiveness of government actions to increase growth.

The new century was marked by fundamental changes in the functions of the state in modern national economies, the quantitative and qualitative parameters of which have not yet been satisfactorily explained by researchers [3]. And, meanwhile, an increasingly significant part of GDP created by national communities is redistributed through the public finance mechanism. For example, the dynamics of state revenues of the advanced countries of the world as a share of GDP shows their steady growth in the period from 2010 to 2020 . The only exception is Denmark, which is distinguished by the highest state incomes among the advanced countries of the world, estimated at $54.0 \%$ in 2010 and 50.6\% of GDP in 2020. In all other countries of this group, the share of state revenues in GDP steadily increased in this period: in France, for example, from 49.6 to $51.7 \%$ of GDP, and in the USA - from 29.1 to $30.8 \%$ of GDP, respectively [4].

As for budget expenditures that provide the state with necessary funds to fulfill its obligations to society, the tendency of their change over the period from 2010 to 2020 is opposite as compared with the above described [5]. So for the period from 2010 to 2020 the share of government spending in the GDP of advanced countries is declining: in Denmark from 56.7 to $50.9 \%$ of GDP; in France - from 56.4 to $50.9 \%$ of GDP, in the USA - from 40.0 to $37.9 \%$ of GDP, respectively. Thus, multidirectional trends in government revenues and expenditures relative to GDP in advanced countries make the problem of inefficiency of the state's activity both in terms of current fulfillment of obligations and its multiplication in the parameters of accumulated public debt relative to GDP (Table 1).

Table 1. Advanced countries: gross debt of the consolidated governments, 2010-2020 (in

\begin{tabular}{|l|c|c|c|c|c|}
\hline Years & 2010 & 2015 & 2018 & 2019 & 2020 \\
\hline Countries & & & & & \\
\hline Australia & 3.9 & 17.8 & 19.2 & 18.7 & 17.3 \\
\hline Austria & 60.5 & 58.0 & 51.9 & 49.4 & 47.5 \\
\hline Belgium & 88.4 & 93.1 & 88.6 & 87.1 & 85.7 \\
\hline Canada & 26.8 .0 & 27.7 & 27.4 & 26.6 & 25.7 \\
\hline Denmark & 15.1 & 16.2 & 16.5 & 16.4 & 16.1 \\
\hline France & 73.5 & 86.5 & 87.0 & 86.9 & 85.8 \\
\hline Germany & 60.9 & 51.2 & 41.5 & 38.1 & 35.1 \\
\hline Italy & 104.7 & 119.5 & 118.5 & 116.5 & 114.1 \\
\hline $\begin{array}{l}\text { United } \\
\text { Kingdom }\end{array}$ & 68.4 & 79.6 & 79.6 & 79.6 & 79.6 \\
\hline
\end{tabular}




\begin{tabular}{|l|c|c|c|c|c|}
\hline $\begin{array}{l}\text { United } \\
\text { States }\end{array}$ & 70.1 & 80.5 & 81.4 & 82.7 & 76.2 \\
\hline $\begin{array}{l}\text { Global } \\
\text { Average }\end{array}$ & 69.6 & 75.7 & 75.0 & 74.5 & 74.1 \\
\hline $\begin{array}{l}\text { G20 } \\
\text { Advanced }\end{array}$ & 75.7 & 81.0 & 80.6 & 80.4 & 80.0 \\
\hline
\end{tabular}

Judging by the parameters of the gross debt accumulated by all levels of government in the advanced countries of the world for the period from 2010 to 2020, its value at the end of the analyzed period allows the author to raise the question of the general threat of the state as an entity spending a significant part of the GDP created by national societies. Indeed, by 2020 only Denmark (16.1\% of GDP); Australia (17.3\% of GDP) and Canada (25.7\% of GDP) were characterized by modest shares of GDP, which estimate the state debts as compared with the total annual results of the entire national society. According to IMF experts, on average this indicator for all developed countries of the world is projected at $80 \%$ of GDP, including, for example, $114.1 \%$ of GDP for Italy; $85.8 \%$ for France; $76.2 \%$ for the USA [7].

In other words, greater or lesser imbalance in the public finance system is typical for all countries of the world, and it raises many questions in the context of the universal tendency to slow down the growth rate of the entire global economy, including developed countries of the world.

\section{PPP projects in the field of public infrastructure - the basis for accelerating economic growth}

The contribution of states to the dynamics of the economic development of their countries can be assessed positively if it is accelerating and negatively if it slows down. These arguments predetermined the significantly increased importance of the choice of factors that can increase the efficiency of the state (at least in terms of its budget expenditures). It is no coincidence that at the first summit of the World Economic Forum, which took place in September 2017, the problem of Sustainable Development of the countries all over the world was unanimously associated with various forms of PPP organization [8]. According to politicians, scientists and practitioners, only partnership mechanisms between the state and private business will achieve the "Sustainable Development Goals" and implement the provisions of the Paris Climate Agreement by 2030 [9]. This importance of PPP should be interpreted in the context of the need to form and to expand the organizational structures of partnership (cooperation, cooperation) of the state and private business, the potential of which is huge, and the degree of implementation is insignificant.

All of the above is fully true for modern Russia. The solution to the problem of largescale construction and reorganization of public infrastructure in the country at all levels: federal, regional and municipal - is possible only within the framework of a system of mutually supportive long-term financing both from the authorities, and from institutional and private investors. In this regard, the consolidation of state budget funds should be accompanied by a change in the structure of the financial market, which requires institutional support for the functioning of the debt financing segment for public infrastructure PPP projects. For these purposes, it is necessary to institutionalize an appropriate instrument for mediating relations between participants in hybrid agreements in the form of PPP projects, for example, infrastructure bonds, to determine the possibility of participation in the pool of investors for institutional players and investors who have returned their capital to the country in connection with anti-Russian sanctions, etc. [10]

The problem of the lack of ready-to-launch and well-structured projects in the infrastructure investment market is becoming more acute every year. So far, it has been 
impossible to overcome, despite the authorities wishing to develop infrastructure at an accelerated pace in the next six years. Besides, it is precisely this factor that hinders the ambitious plans. According to the InfraONE' assessment RUB 2.2-2.7 trillion are available in the financial market for infrastructure. However, the lack of projects hinders the funds to reach the construction site. Implementation of a systematic approach to strategic territory development, transparent tender procedure, development of seed funds, dealing with problems of construction market and competency building in construction management are the steps that, in our opinion, will address the challenges in the long term (five-six years horizon, if get moving right now). However, to increase the number of the ready-to-launch projects is possible even in the coming years - in this regard projects' authors may pay their attention to underestimated financial instruments at the market, in order to make the project bankable, while authorities may hasten the emergence of alternative state aid and new investment mechanisms [11].

In 2019, the minimum additional requirements of Russian infrastructure are RUB 2.6 trillion (or 2.4\% of GDP). By 2024, this figure is likely to reach RUB 4.8 trillion. However, under the conservative economic growth forecast scenario from the Ministry of Economic Development, it may reach RUB 5.85 trillion; under the base forecast scenario, it may reach RUB 6.1 trillion. According to the Russian Treasury, as of December 2018, the budgetary spending on infrastructure decreased to RUB 1.9 trillion, or $1.8 \%$ of GDP in 2018, compared to RUB 2 trillion, or $2.2 \%$, in 2017. In terms of GDP share, the investments fell to a sevenyear record low (Fig. 1).

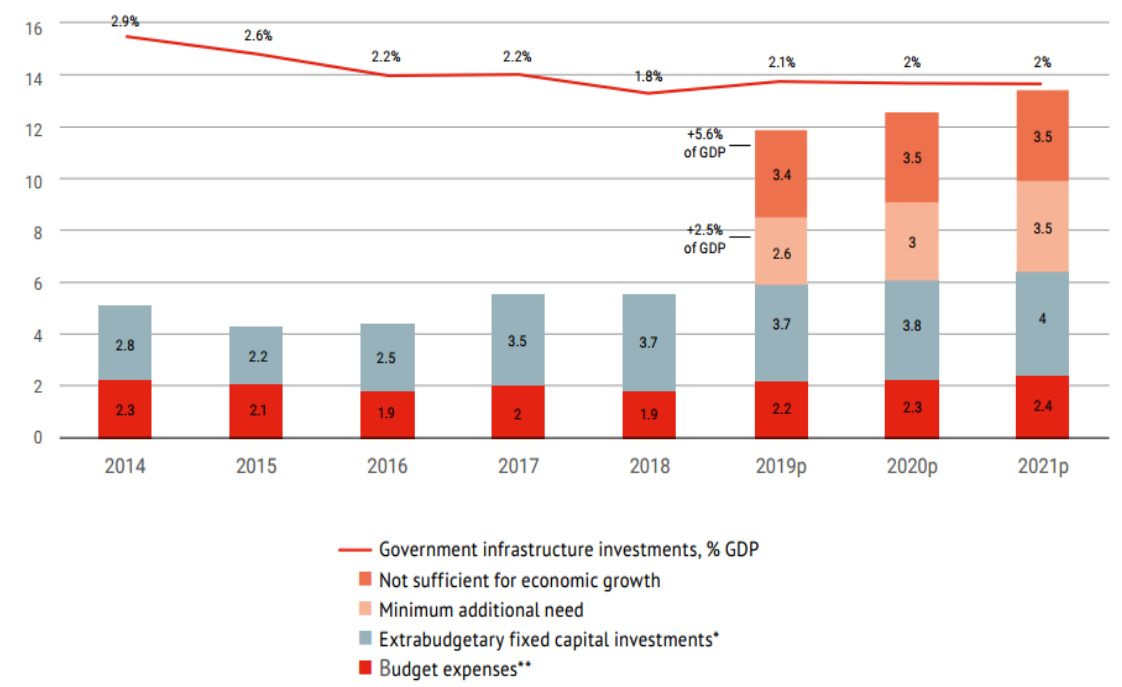

Fig. 1. Infrastructure investment trends and infrastructural needs in Russia, RUB trillion [12]

The ratio of budgetary to extra-budgetary funds has shifted even further in the direction of the latter, reaching 1:1.85. But this is still not enough to develop infrastructure, and the major portion of funds is spent on the maintenance of existing facilities [13].

Investments in projects under the comprehensive plan for backbone infrastructure can cover the minimum additional requirements of national infrastructure through 2022-2023. By the end of the five-year period, investments in infrastructure will be used for economic growth. However, this is an optimistic scenario that does not consider any systemic constraints. If the budget funds allocated for infrastructure will be disbursed on time, and the projects involving extra-budgetary funding will become available at a somewhat slower pace than the government plan (two to three years later than on schedule), then the additional 
minimum requirement will not be met by 2024 , and the underfunded share will be about $10 \%$.

However, the third scenario, which takes into account a significant part of constraints, is most probable. If the lack of projects can be overcome only in 2021 (which will lead to a significant but realistic investment spurt), the minimum additional requirements of national infrastructure will be met by almost two thirds by 2024 . The actually invested amount will also be RUB 3.8 trillion instead of the RUB 6.35 trillion earmarked in the comprehensive plan. Although infrastructure investment market in Russia has been developing for several decades, nevertheless there is still no consistent source that would give clear answers to the following questions: what projects are being discussed, whether they will be implemented in the public-private partnership format, and how much investment is expected [14].

\section{Results and Discussion}

The use of different project financing mechanisms and forms in the Russian infrastructure market is expanding, but many of these tools remain underused and not understood by either the state or the business community. This significantly limits the number of projects. According to our estimates, about RUB 2.2 to 2.7 trillion are available for infrastructure investment. This money can cover the minimum additional infrastructure investment need of the country (RUB 2.6 trillion). But due to the lack of projects on the market, Russian public infrastructure receives only a modest share of the potential private investment. But the public investments in infrastructure have so far been mainly aimed at maintaining the existing capacities. Often there are no legislative barriers to the use of complex financial instruments but both the financial institutions and project authors lack experience in their implementation. This means that funds are raised for a project mainly through traditional loans. But many projects require a more complex financial structure for their economic sustainability. This allows to distribute risks between the funding organizations, to reduce the cost of funds and increase the project attractiveness for private players [15].

Having such important instruments of fiscal impact on macroeconomics, the state meets the opportunity to get a significant return on capital expenditures' scale of the federal budget with the help of organizational factors of PPP projects in infrastructure, capable to increase greatly their efficiency. Using official data, the author made some estimates of the prospects for increasing capital investments in infrastructure, without increasing this item of federal budget expenditures. The data obtained were structured in the following tables (Table 2).

Table 2. Russia: estimation of economic effect obtained from attracting private investments to the rouble of budget funds into the infrastructure projects in current prices $(*$ - forecast)

\begin{tabular}{|c|c|c|c|c|c|}
\hline Years & $\begin{array}{c}\text { Federal budget' } \\
\text { expenditures, } \\
\text { billion rubles }\end{array}$ & $\begin{array}{c}\text { Capital } \\
\text { expenditures } \\
\text { of federal } \\
\text { budget, billion } \\
\text { rubles }\end{array}$ & $\begin{array}{c}\text { Effect of scale of } \\
\text { capital expenditures } \\
\text { of federal budget in } \\
\text { the ratio: } 1 \text { budget } \\
\text { ruble }: 1 \text { private } \\
\text { rubles (billion rubl.) }\end{array}$ & $\begin{array}{c}\text { Effect of scale of } \\
\text { capital expenditures of } \\
\text { federal budget in the } \\
\text { ratio: } 1 \text { budget ruble: }: \\
1.5 \text { private rubles } \\
\text { (billion rubl.) }\end{array}$ & $\begin{array}{c}\text { Effect of scale of capital } \\
\text { expenditures of federal } \\
\text { budget in the ratio: } 1 \\
\text { budget ruble : } 3 \text { private } \\
\text { rubles (billion rubl.) }\end{array}$ \\
\hline 2012 & 11396.09737 & 565.7602299 & 1131.52046 & 1414.400575 & 2263.04092 \\
\hline 2013 & 13342.90264 & 548.5042132 & 1097.008426 & 1371.260533 & 2194.016853 \\
\hline 2014 & 14830.60135 & 696.9569948 & 1393.91399 & 1742.392487 & 2787.827979 \\
\hline 2015 & 15610.90145 & 658.7588142 & 1317.517628 & 1646.897036 & 2635.035257 \\
\hline 2016 & 16416.44684 & 603.0399593 & 1206.079919 & 1507.599898 & 2412.159837 \\
\hline 2017 & 16420.30308 & 570.6304896 & 1141.260979 & 1426.576224 & 2282.521958 \\
\hline $2018^{*}$ & 16222 & 585 & 1170 & 1462.5 & 2340 \\
\hline $2019^{*}$ & 16194 & 580 & 1160 & 1450 & 2320 \\
\hline
\end{tabular}

Judging by Table 2, the involvement of one additional rouble increases the potential of budget expenditures for infrastructure development by a factor of 2 , which allows doubling 
the initial amount of capital expenditures of the federal budget for infrastructure. So from the amount of investment in infrastructure at the expense of the budget of 565.7 billion roubles in 2012, the amount is twice as much - 1131.5 billion in the same year. Even more significant is the difference in the third column, where, with the use of 3 units of extra-budgetary funds per unit of budget funds, there are already 4 units in infrastructure projects. The last amount of 2263.04 billion roubles in 2012 is already 4 times more than the same amount in 2012 without raising funds at all.

In order to approximately estimate the economic effect of state involvement in nonbudgetary funds in infrastructure projects, we averaged the coefficient of elasticity (fiscal multiplier) and estimated the effectiveness of the treatment of attracted capital of PPP participants in public infrastructure projects. With an elasticity of about 1.04 (104\%), we received a return on the most modest version of the ratio of the budget and extra-budgetary funds 1 to 1 in infrastructure at the level of 1,179.4 billion roubles. in 2012, and by 2019 this effect has increased to $1,209.1$ billion. According to the most optimal variant with the ratio of budget and private investment as 1 to 3 , this effect increased to 2358.8 billion roubles up to 2418.2 billion for the period of $2012-2019$.

Below 4 scenarios are presented in order to assess the economic benefit as a result of increasing return on budget capital expenditures' scale: (1) officially approved budget for expenditures and if the government could manage to attract private investment in the following ratios: (2) 1 budget rouble to 1 private rouble; (3) 1 budget rouble to 1.5 private roubles; and (4) 1 budget rouble to 3 private roubles (on the data base of Table 2) (Fig. 2).

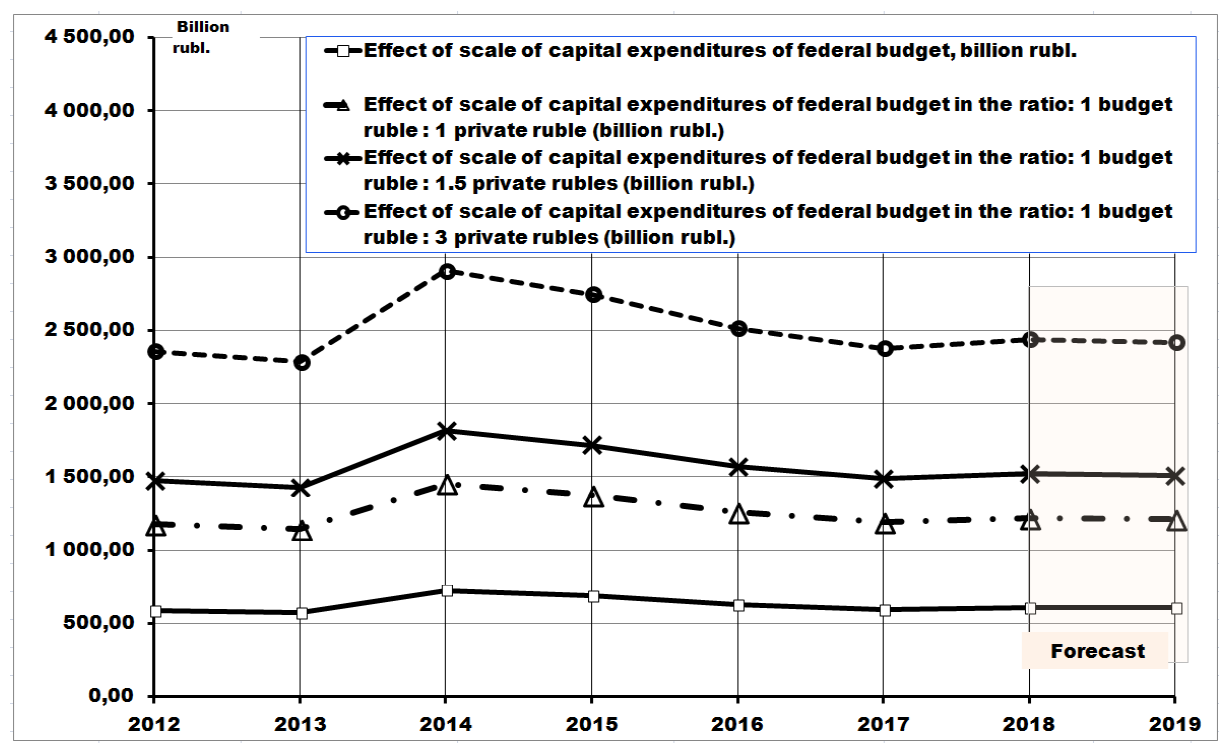

Fig. 2. Russia: dynamics of the effect of scale obtained from attracting private investments to the rouble of budget funds into the infrastructure projects in current prices (in billion rubles)

All above mentioned gives the idea of the magnitude of capital expenditures, which are constantly falling in shares of GDP: from $0.83 \%$ in 2012 to 0.55 - in 2019 (forecast). Recalculation of these indicators in current prices allowed obtaining absolute values of infrastructural capital investments, which practically did not change for the whole analyzed period: in 2012 they amounted to 565.7 billion roubles, and in 2019 - 580 billion (forecast). When the development of infrastructure becomes the decisive factor ensuring the stability of 
economic growth and, therefore, of financial stability, such scale of capital investments can be estimated as insignificant. But it should be remembered that in the context of fiscal consolidation, the state cannot spend additional funds to the public infrastructure.

\section{Conclusion}

After the global economic shocks of the early 21 st century, the movement for the priority of long-term investments as the main factor of sustainable development is actively developing abroad. According to the World Bank's forecast, by 2018, global economic growth will drop to $3 \%$, and infrastructure development will be a key factor in improving well-being. Large institutional investors are combined to develop practical tools and approaches to stimulate the use of long-term behaviour in making investment decisions by the largest asset owners pension funds, insurance companies and investment funds.

It has been used the methodology of system approach in connection with abstraction, analysis, and synthesis methods to identify the contradiction between a stable cut in budget expenditures as a share of GDP, on one hand, and growing necessity for public financing of public infrastructure, on the other. It has been proved that the only way out is connected with the choice of the priority function of the government, that could give the multiplying effect. Modelling the structure of budget expenditures for the purpose of assessing their effectiveness has showed that such a promising direction of public expenditures is the public infrastructure. It is the latter, being a public goods, has turned out to be exclusively capitalintensive, requiring long-term investments and capable, under certain circumstances, to bring a multiple economic returns. The analyses has proved that now public infrastructure building and restructuring are the fundamental factor of the Russian economy' accelerated growth because of the backward infrastructure often still of Soviet origin. It has become evident that accelerated development of many public infrastructure PPP-projects is hampered by two factors: (1) inadequate state institutional support for the design process itself and (2) absence of state-prepared acceptable financial models of public infrastructure PPP-projects regarding the division of risks of infrastructure projects and delegating the proprietary rights of the state to private investors.

Modelling the resultant of substitution of budget funds by private investment in public infrastructure PPP-projects let the authors evaluate the negative and positive impacts of the budget consolidation on the economic systems' dynamic characteristics as well as reduce the negative consequences to zero or achieve positive effects. These problems are being developed in this chapter for the purpose to manage national budget fund efficiency using the preferences of the government and of the private investors in the sphere of public infrastructure as well as of their organization form of cooperation - PPP - in the conditions of forced fiscal constraints. Under certain conditions public infrastructure could be the fundamental long run factor of Russian economy' development. This is consistent with the results of our estimates of fiscal multipliers for Russia, which showed that the reduction in budget spending has a significantly smaller negative impact on GDP growth compared to a similar increase in the tax burden. Based on assessments of the elasticity coefficients, the direct negative impact of fiscal consolidation on GDP growth for 2018-2020 may be cumulatively only about 0.3 percentage points. But this is the case if the state does not use public infrastructure PPP-projects to attract private investments, which will significantly improve the efficiency of budget expenditures. The variety of forms of organization of PPP allows in each case to vary the conditions for the implementation of projects by optimizing the distribution of risks between partners, sharing ownership rights between them, etc. It is the joint actions of the state and private business that can keep the global economy from sliding to negative values of economic growth. 


\section{References}

1. IMF. World Economic Outlook Update. January (2020)

2. Vaslavskaya I. Yu. Public-private partnership and financing the development of national infrastructure: safeguarding public finance sustainability. In: Social, Economic, and Environmental Impacts between SustainableFinancial Systems and Financial Markets. Ed. by Magdalena Ziolo. Hershey PA, USA: IGI Global (2020)

3. Tanzi V., and L. Schuknecht. Public Spending in the 20 $0^{\text {th }}$ Century: A Global Perspective. Cambridge: Cambridge University Press (2000)

4. International Monetary Fund (IMF). Fiscal Monitor: How to Mitigate Climate Change. Washington, October (2019)

5. World Bank. Global Economic Prospects, January 2019: Darkening Skies. Washington, DC: World Bank. (2019)

6. International Monetary Fund (IMF). Fiscal Monitor: Managing Public Wealth. Washington, October (2018)

7. International Monetary Fund (IMF). Fiscal Monitor: Managing Public Wealth. Washington, October (2018)

8. WEF. Sustainable Development Impact Summit, September, Geneva: WEF (2017)

9. World Economic Forum. The Inclusive Growth and Development Report, 2017. Geneva: WEF (2017)

10. World Bank. Restoration of the Russian economy: how stable are the growth signs? Report on the Russian Economy. 38. November (2017)

11. InfraONE. National Infrastructure Projects Pipeline. Analytical review. Moscow: InfraONE (2019)

12. Infrastructure Investment: at which point investors' interests meet government concerns. Analytical Review. Moscow: InfraONE (2019)

13. Vaslavskiy Y., and I. Vaslavskaya. Infrastructure public-private partnership projects: budget consolidation policy in Russia and government expenditures efficiency increase In: Modeling Economic Growth in Contemporary Russia. Edited by Bruno S. Sergi. Bingley: Emerald Publishing (2019)

14. Hallegatte, Stéphane, Jun Rentschler, and Julie Rozenberg. Lifelines: The Resilient Infrastructure Opportunity. Sustainable Infrastructure Series. Washington, DC: World Bank (2019)

15. World Bank. Russia Economic Report. \#42. December 4 (2019) 